Proc. Estonian Acad. Sci. Biol. Ecol., 2003, 52, 2, 91-111

\title{
Water environment of Haapsalu Bay in retrospect (1975-2000)
}

\begin{abstract}
Andres Jaanus
Estonian Marine Institute, University of Tartu, Marja 4D, 10617 Tallinn, Estonia, andres@phys.sea.ee

Received 15 April 2002, in revised form 2 October 2002

Abstract. A complex study with 12 series of measurements of physical, chemical, and biological parameters (temperature, salinity, $\mathrm{O}_{2}$, Secchi depth, concentrations of tot- $\mathrm{N}$, tot- $\mathrm{P}, \mathrm{NO}_{3}-\mathrm{N}, \mathrm{PO}_{4}-\mathrm{P}$, chlorophyll $a$, and phytoplankton species composition and biomass) was carried out in Haapsalu Bay from March to October 2000. The results are compared with the studies in 1975-90. Calculations made for the total phosphorus vs. chlorophyll $a$ concentrations in Haapsalu Bay in 2000 indicated a moderate positive correlation $\left(r^{2}=0.36 ; n=57\right)$, whereas the relationships between total nitrogen and chlorophyll $a$ were weak $\left(r^{2}=0.05 ; n=57\right)$. The relative biomass of cyanobacteria increased continuously until October, reaching $93-94 \%$ of the total in the eastern part of the bay, while in the central and western parts their share varied in the range $39-88 \%$ and $4-43 \%$, respectively. Proliferation of phytoplankton in late summer was common in the eastern bay also in the 1970s. The average total phytoplankton biomass values in August 1976-85, 1989, and 2000 were 0.1-1.8, 3.3, and 7.2 mg/L, whereas in eastern Haapsalu Bay they were $0.8-8.2,1.8-12.9$, and $5.2-13.3 \mathrm{mg} / \mathrm{L}$, respectively.

Although the general succession of phytoplankton communities in Haapsalu Bay has not altered and the biomass values obtained in 2000 were similar to those calculated from the earlier samples, a simple increase in nutrient concentrations and algal biomass will bring about greater environmental risks connected with cyanobacteria.
\end{abstract}

Key words: coastal waters, nutrients, chlorophyll $a$, phytoplankton.

\section{INTRODUCTION}

The aim of the present paper is to describe the environmental conditions and phytoplankton dynamics in Haapsalu Bay based on the field measurements performed in 2000 (see Fig. 1 for the location of sampling stations) and to discuss possible alterations in the ecosystem of the bay during the last two decades. Earlier (in 1975-79, 1985, 1989) measurements were repeatedly carried out by scientists of the Institute of Zoology and Botany (Estonian Academy of Sciences). Still, those observations have not followed very regular seasonal patterns and fulfilled the optimum requirements for coastal monitoring. Nevertheless, some earlier data give valuable information on the environmental conditions (e.g. dissolved oxygen and nutrient concentrations) in wintertime, which play an important role in the functioning of the whole planktonic ecosystem during the vegetation period. 


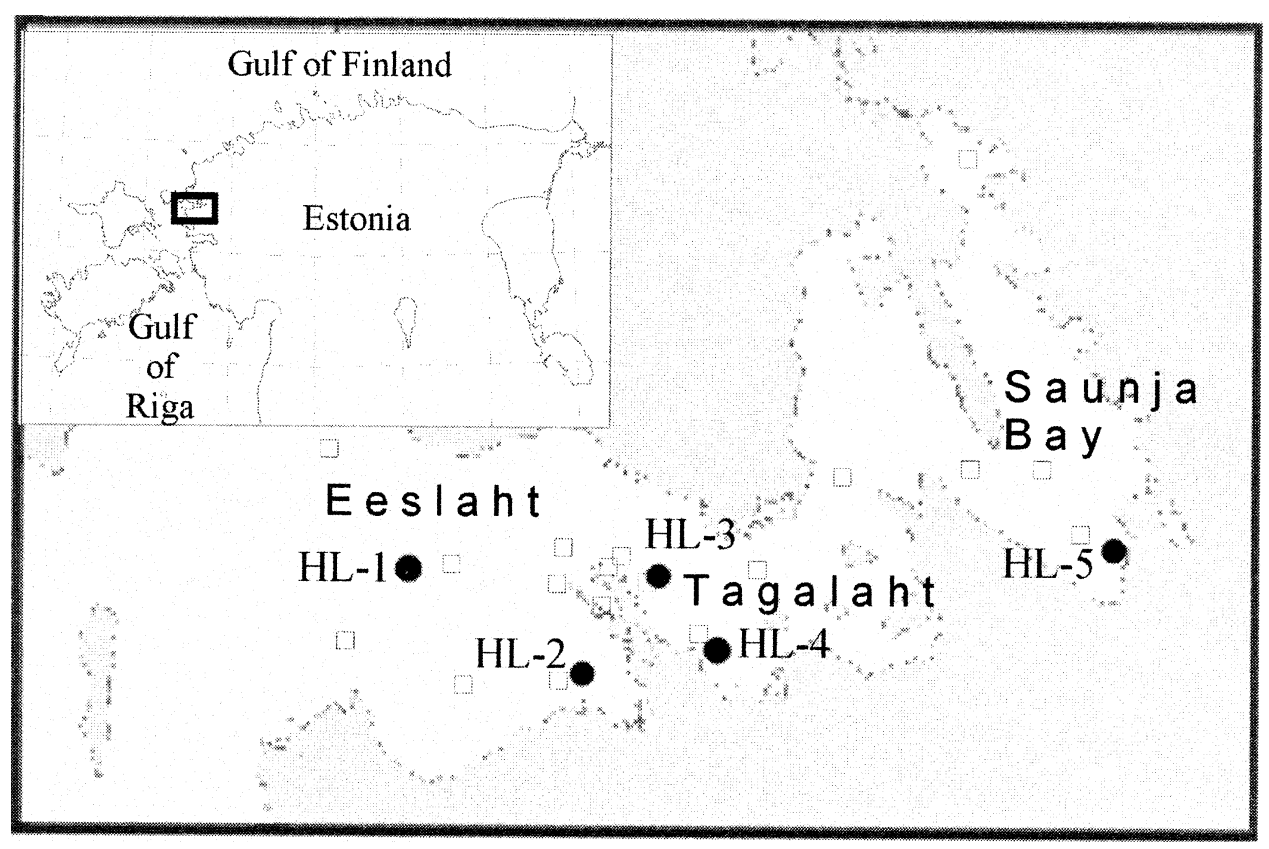

Fig. 1. Study area and location of sampling stations in 2000 (filled circles) and in 1989 (empty squares).

\section{STUDY AREA}

Haapsalu Bay is a part of the Väinameri (Moonsund) area, which can be regarded as a connecting link between the Gulf of Riga and the open Baltic Sea. About $85 \%$ of the water exchange of the Väinameri area takes place through the straits of Muhu (Suur Väin) and Hari Kurk (Mardiste, 1974). According to the last periodic assessment of the state of the Baltic Sea environment, the area north of the straits of Muhu is considered to belong to the northern Baltic Proper (HELCOM, 2001a).

The sinuous coastline of West Estonia and the archipelago zone with the outflow of several small rivers creates very variable hydrological conditions. Narrow and shallow Haapsalu Bay is located at the western coast of Estonia. The maximum depth in its open western part (Haapsalu Eeslaht) is only $4.5 \mathrm{~m}$. The mean depth in the central and eastern parts of the bay does not exceed 1-2 m. Some of the small rivers (Taebla, Võnnu, Uuemõisa, and others) bring nutrient-rich fresh water into the eastern part of Haapsalu Bay. The water exchange between the eastern and central parts of the bay separated by peninsulas is limited. The vertical gradient of water temperature is missing during the summer period due to the shallowness of the bay. The central part of the bay (Haapsalu Tagalaht) receives municipal and industrial sewage waters from the town of Haapsalu (13 000 inhabitants).

A mechanical wastewater treatment plant (WWTP) was reconstructed in 1981. The next reconstruction of the existing WWTP started in 1995 and was completed 


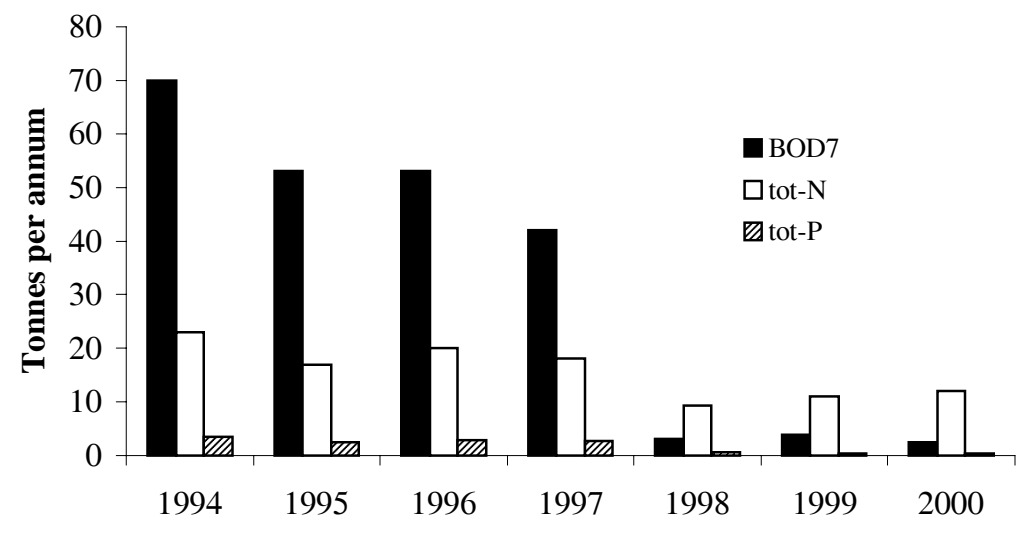

Fig. 2. Pollution load of Haapsalu Bay in 1994-2000 (HELCOM, 2001b).

in 1997. As a result, the pollution load decreased notably. As Fig. 2 shows, BOD and phosphorus levels decreased thanks to the WWTP despite the fact that nitrogen concentrations were still at a too high level. By January 2001 the construction works for nitrogen removal and sand separation were finalized (HELCOM, 2001b).

\section{MATERIAL AND METHODS}

In 2000 a complex study with 12 series of the measurements of physical, chemical, and biological parameters was carried out from March to October. At all stations the surface layer $(\sim 0.5 \mathrm{~m})$ water was measured and sampled. At two stations in Haapsalu Eeslaht, the near-bottom water layer was additionally investigated. For hydrochemical analysis discrete samples were treated while the samples for phytoplankton and chlorophyll $a$ analysis were pooled. To achieve better comparability with earlier (1975-79, 1985, and 1989) results, in this paper the obtained results are averaged for each station as the differences between these two layers were rather slight in most of the cases.

Temperature and salinity profiles were obtained using the conductivitytemperature-depth (CTD) profiler SBE-19. Dissolved oxygen concentrations were measured with a Marvet-Junior thermo-oxymeter. Samples for nutrient, chlorophyll $a$, and phytoplankton analyses were collected with a plastic 3.5 litre water sampler. Chemical analyses were performed by the Estonian Environmental Research Centre using ISO standard methods.

For chlorophyll $a$ analyses, 0.1-1 L (depending on the density of the sample) of water was filtered through $47 \mathrm{~mm}$ Whatman $\mathrm{GF} / \mathrm{F}$ filters under the pressure of $\sim 0.3 \mathrm{~atm}$ and extracted for $24 \mathrm{~h}$ in darkness at $4-6^{\circ} \mathrm{C}$ with $5 \mathrm{~mL}$ of $90 \%$ acetone. The extract was measured spectrophotometrically (Secomam S250I) at 630, 647, 663, and $750 \mathrm{~nm}$. Chlorophyll $a$ concentrations were calculated according to Jeffrey \& Humphrey (1975). 
Samples for quantitative analysis of phytoplankton were fixed with acetic Lugol's solution to a final concentration of $0.5 \%$. The fixed sample (10 to $50 \mathrm{~mL}$ ) was settled in a sedimentation chamber for $\geq 24 \mathrm{~h}$ and counted using an inverted microscope Olympus IM. Wet weight biomass of phytoplankton was calculated from cell geometry (HELCOM, 1988; Hillebrand et al., 1999) and using cell volume tables (Phyto, Software Kahma Ky) or after original measurements. Heterotrophic dinoflagellates as well as the autotrophic ciliate Mesodinium rubrum were counted with autotrophic phytoplankton and their biomasses were related to the total phytoplankton biomass.

\section{RESULTS}

\section{Water temperature and salinity}

Haapsalu Bay is characterized by rapidly increasing water temperature during the spring period and by relatively high temperatures in the summer months (19$22^{\circ} \mathrm{C}$ ). Water salinity showed differences between the western and eastern parts. The salinity in the open western part was comparable to that in the adjacent Väinameri area (6-7 PSU; Fig. 3). In Haapsalu Tagalaht (stations HL-3 and HL-4)
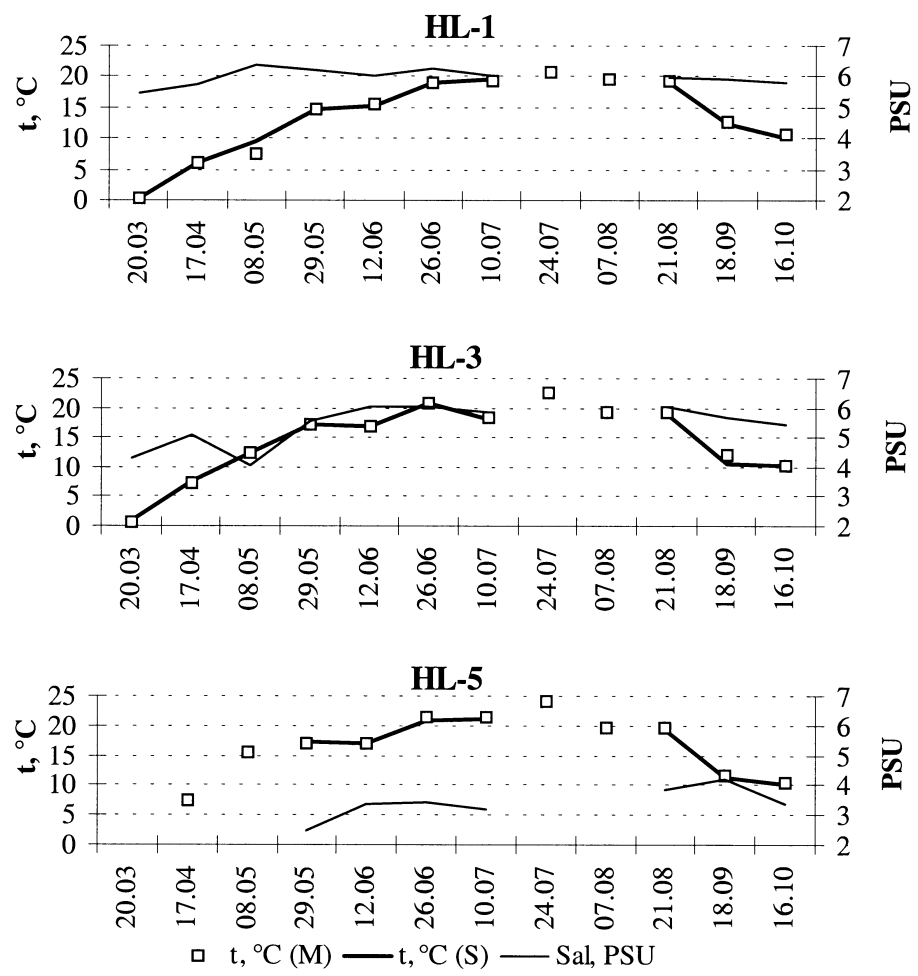

Fig. 3. Seasonal variation of water temperature $\left({ }^{\circ} \mathrm{C} ; \mathrm{M}-\right.$ Marvet Junior, S - SBE-19) and salinity (PSU) in Haapsalu Eeslaht (HL-1), Haapsalu Tagalaht (HL-3), and Saunja Bay (HL-5) in 2000. 
the lowest values (3.1-4.0 PSU) were obtained at the beginning of May. In Saunja Bay (HL-5) the salinity values varied between 2.5 and 4.2 PSU during the observation period, being also the lowest at the beginning of May due to the freshwater inflow from several small rivers and streams.

\section{Secchi disc transparency}

Water transparency, measured as the disappearance depth of Secchi disc, was relatively good in Haapsalu Eeslaht during the summer and autumn periods (Fig. 4). In most cases the water was transparent to the bottom. The turbidity in

\section{HL-1}

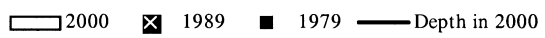

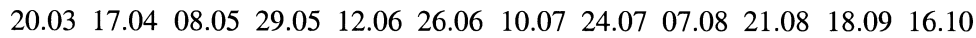

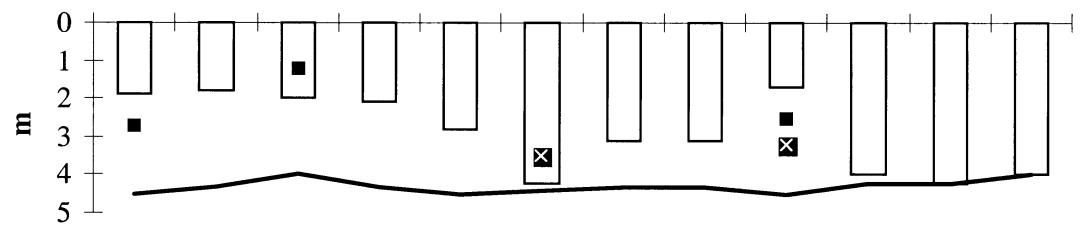

HL-3

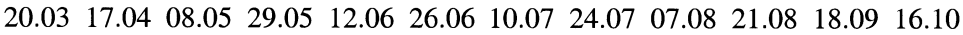

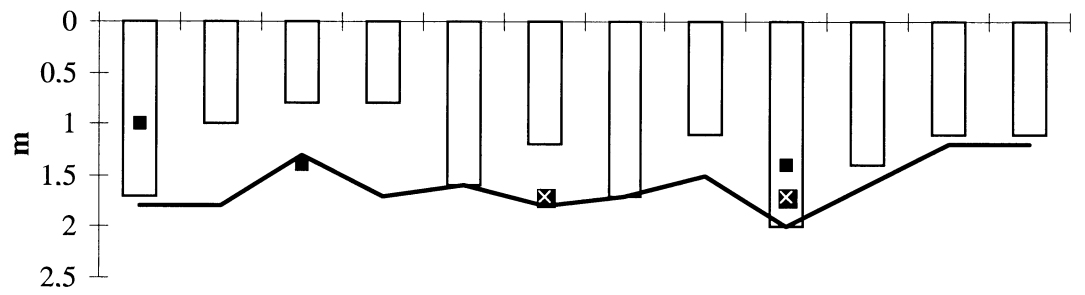

HL-4

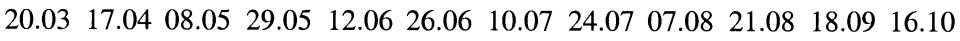

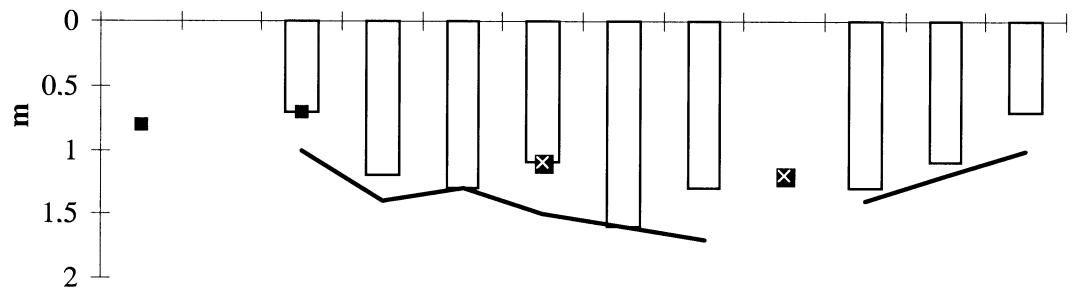

Fig. 4. Secchi disc transparency (m) and the depth of sampling sites in Haapsalu Eeslaht (HL-1) and Haapsalu Tagalaht (HL-3 and HL-4). 
the western part of Haapsalu Bay is mainly caused by wind-induced mixing. In Haapsalu Tagalaht and Saunja Bay resuspension of mud and organic waste from the sea bottom and exceptionally high density of phytoplankton communities are the main factors aggravating water transparency during late summer.

\section{Oxygen conditions}

The oxygen conditions in the surface layer were rather good during the whole vegetation period (Fig. 5). The only exception was found on 24 July at the open bay station HL-1, where the oxygen concentration in the near-bottom water was $0.8 \mathrm{mg} / \mathrm{L}$, probably due to the intensive decomposition of organic matter.

\section{HL-1}

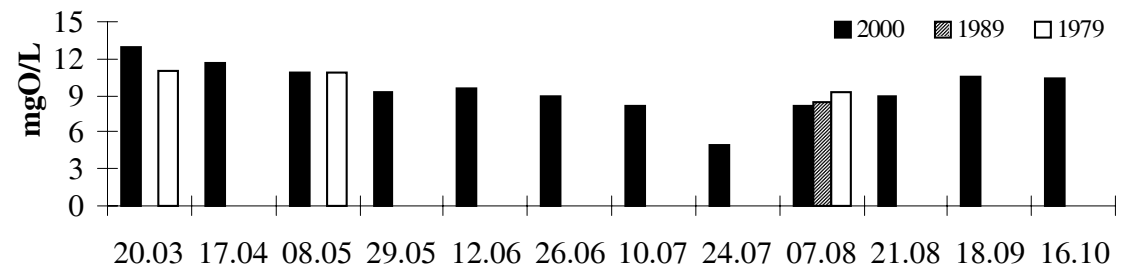

HL-3

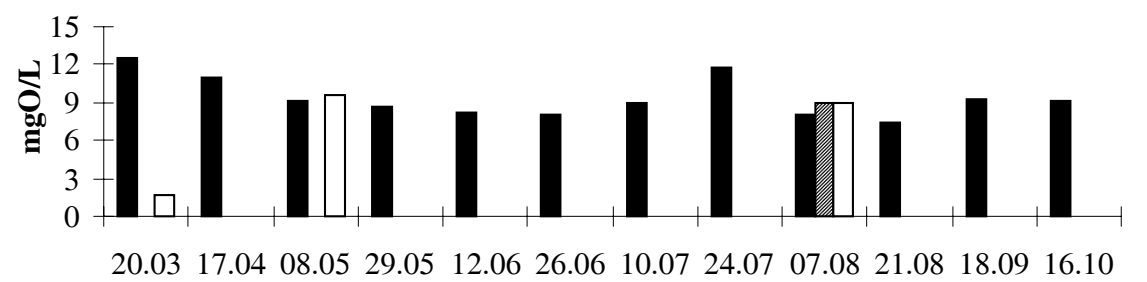

HL-5

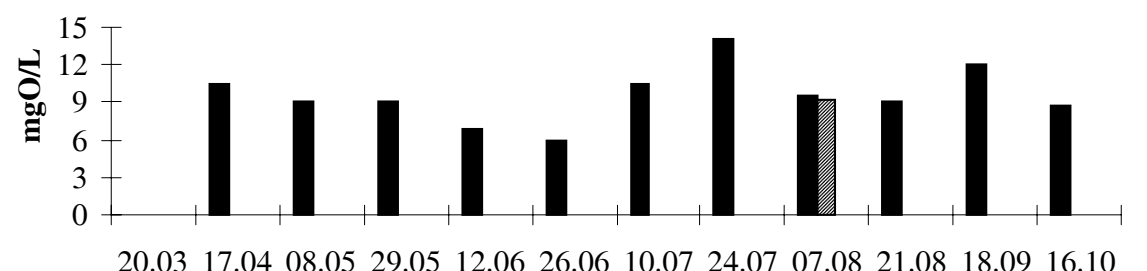

Fig. 5. Dissolved oxygen content in Haapsalu Eeslaht (HL-1), Haapsalu Tagalaht (HL-3), and Saunja Bay (HL-5). 


\section{Total phosphorus}

The concentrations of total phosphorus were higher in Haapsalu Tagalaht the maximum value was recorded on 8 May at the station HL-3 $(2.8 \mu \mathrm{molP} / \mathrm{L}$; Fig. 6). This is still lower than the concentration measured in August 1989 in the vicinity of the sewage outlet $(3.8 \mu \mathrm{molP} / \mathrm{L})$, which is located nearest to the station HL-4. The values obtained in March 1977-79 at the same place were several times higher (16.3-93.1 $\mu \mathrm{molP} / \mathrm{L}$; Porgasaar, 1984). The extremely high concentrations of total phosphorus were probably measured before the vegetation period. In 2000 nutrient concentrations were estimated within the vegetation period.
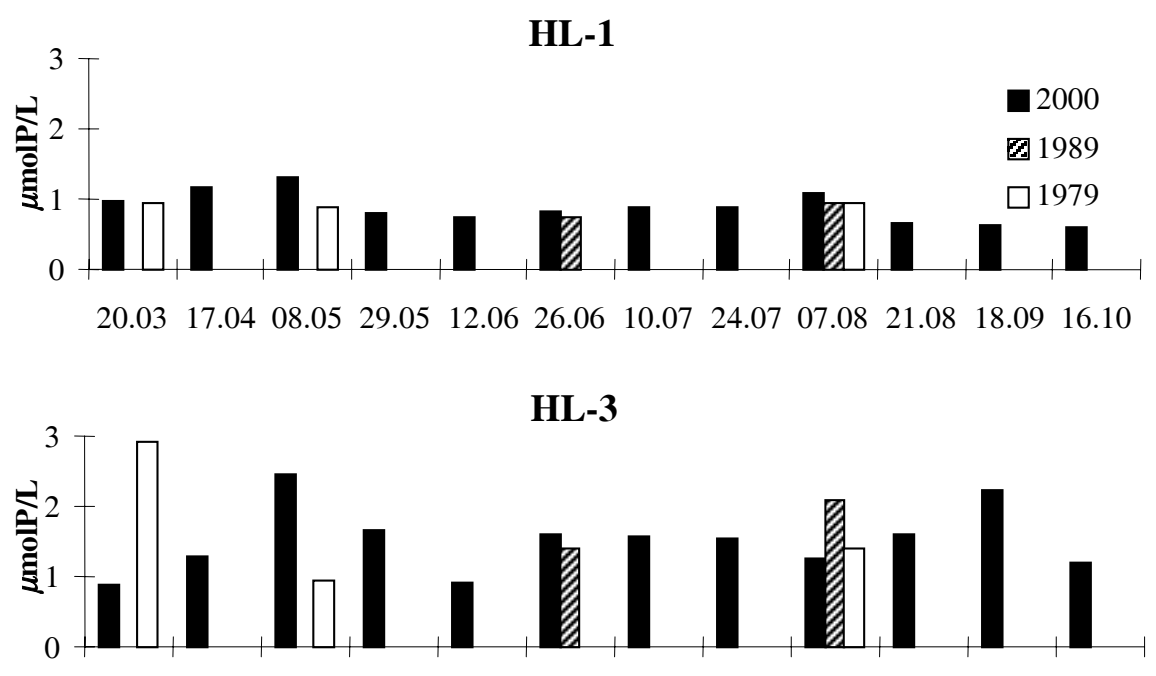

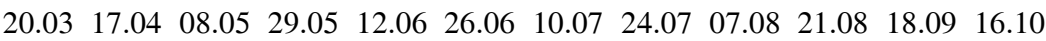

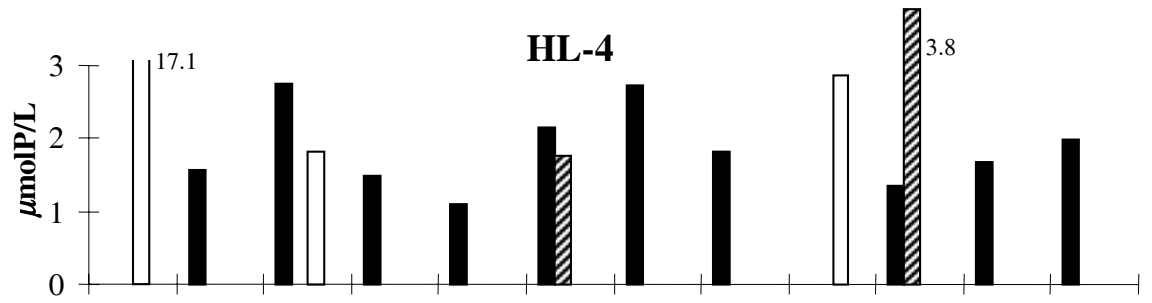

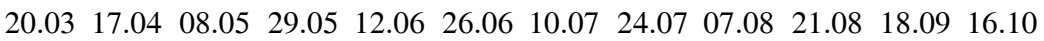

Fig. 6. Total phosphorus concentrations in Haapsalu Eeslaht (HL-1) and Tagalaht (HL-3 and HL-4). 


\section{Total nitrogen}

In general, in 2000 the concentrations of total nitrogen were approximately 1.5-2 times as high as in 1989 (Fig. 7). The greatest difference appeared in Haapsalu Eeslaht, where the abundance and biomass of phytoplankton were rather low during the summer period. The results are somewhat contradictory being most likely caused by the methods used, i.e. the threshold concentrations. In 2000 the concentrations were expressed as $<1 \mathrm{mgN} / \mathrm{L}(\sim 71 \mu \mathrm{molN} / \mathrm{L})$ in several cases, which refers to insufficient precision of the measurements.
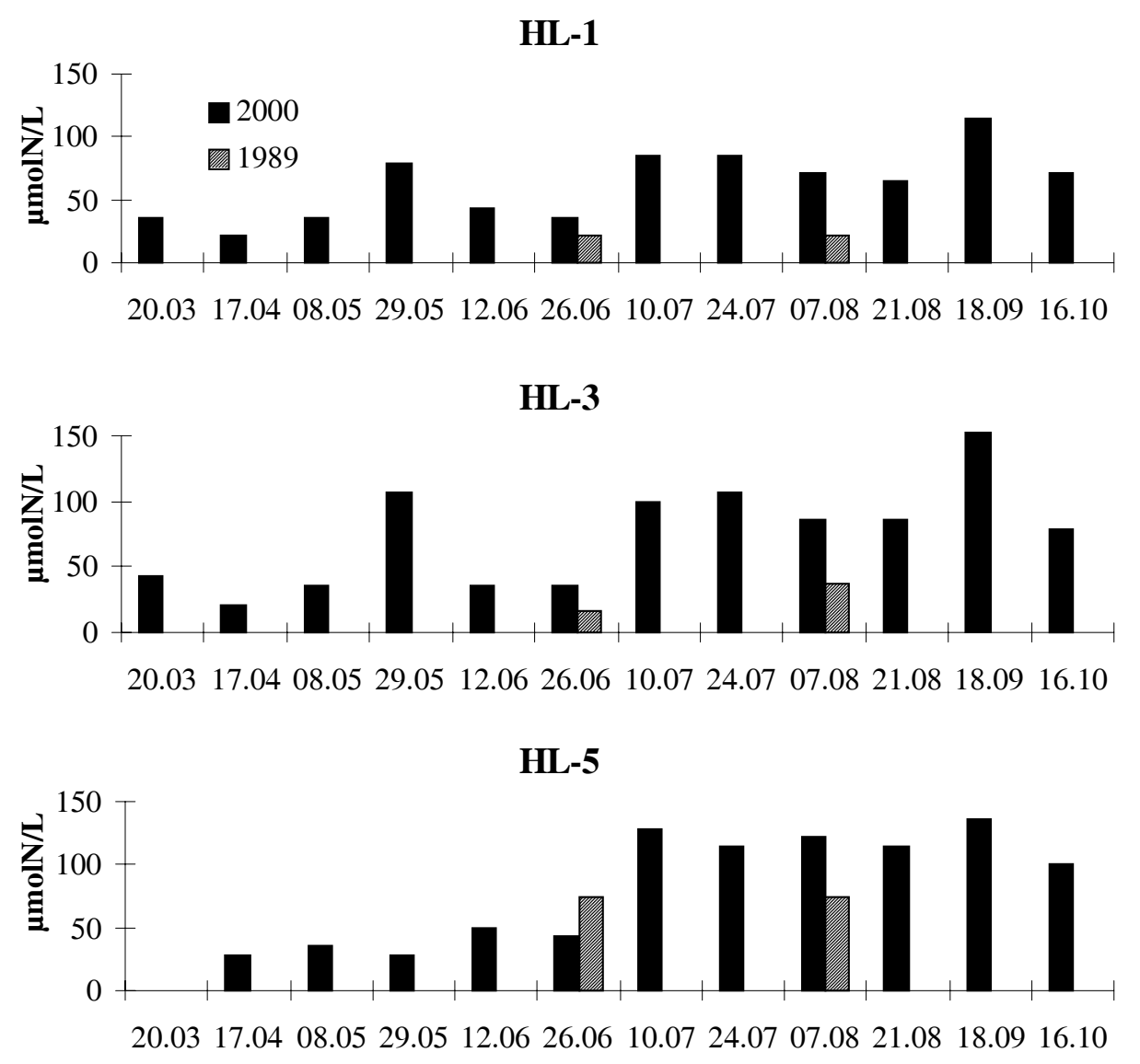

Fig. 7. Total nitrogen concentrations in Haapsalu Eeslaht (HL-1), Tagalaht (HL-3), and Saunja Bay (HL-5). 


\section{Nitrates and phosphates}

The seasonal maxima of dissolved inorganic nitrogen $\left(\mathrm{NO}_{3}-\mathrm{N}\right)$ and phosphorus $\left(\mathrm{PO}_{4}-\mathrm{P}\right)$ were probably not detected during the observation period. By the beginning of the field work phytoplankton had obviously reached the biomass level corresponding to the spring maximum and the concentrations of phytoplankton in Haapsalu Tagalaht and Saunja Bay were relatively high also during the last measurements in October. Therefore, the concentrations of dissolved inorganic nutrients in the water column remained low (Fig. 8).

On the other hand, the maximum concentration of phosphates at the station HL-4 was high in summer $1979(2.3 \mu \mathrm{molP} / \mathrm{L})$. The corresponding value in 2000
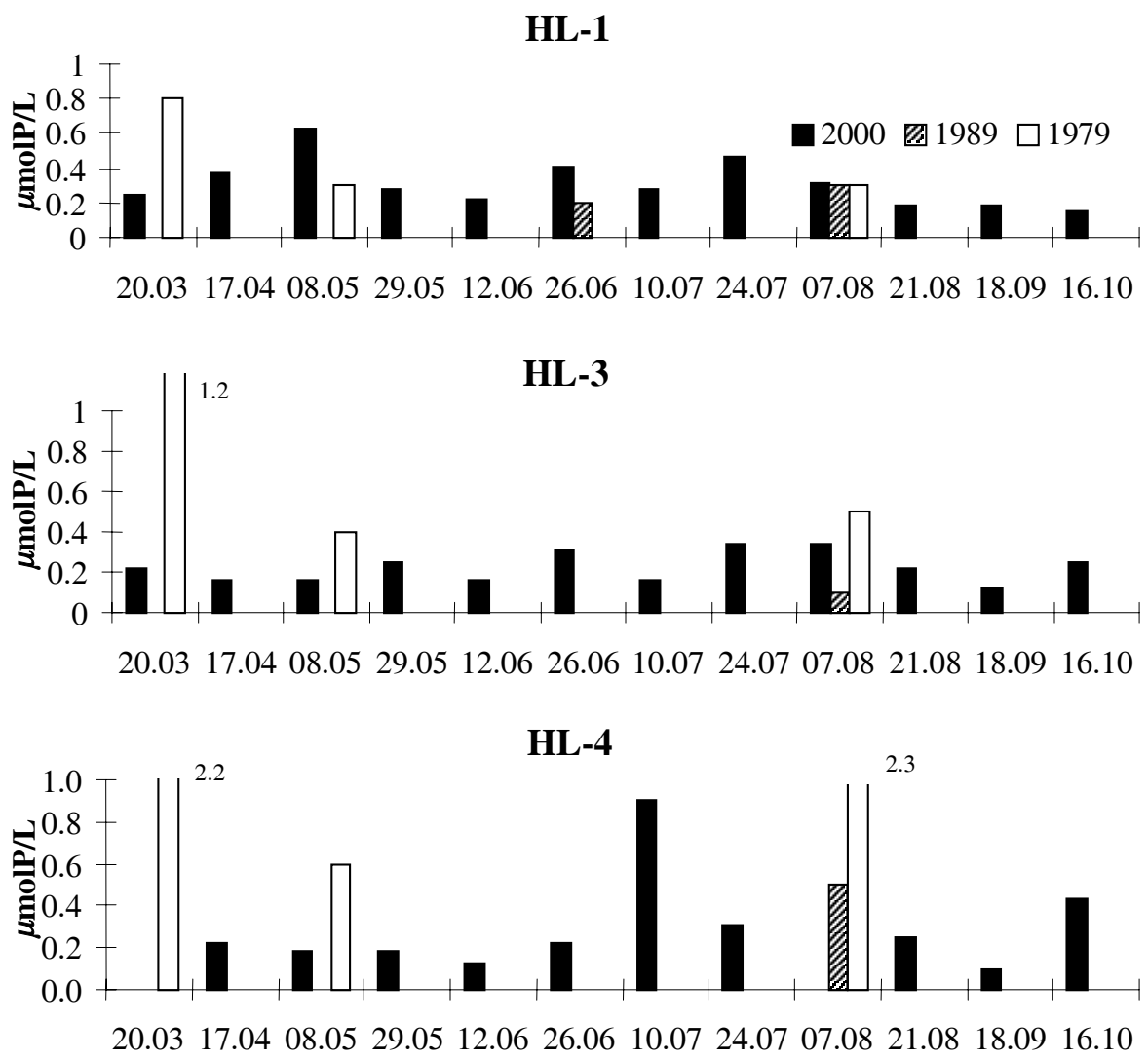

Fig. 8. Concentrations of dissolved inorganic phosphorus in Haapsalu Eeslaht (HL-1) and Tagalaht (HL-3 and HL-4). 
was $0.9 \mu \mathrm{molP} / \mathrm{L}$. In 1989 nitrate concentrations stayed mostly below the detection limit, while in 1979 the concentration of inorganic nitrogen was not determined.

\section{Chlorophyll $a$}

In Haapsalu Eeslaht the annual maximum concentration of chlorophyll $a$ was measured in March $\left(7 \mathrm{mg} / \mathrm{m}^{3}\right)$. Chlorophyll $a$ concentrations remained below $5 \mathrm{mg} / \mathrm{m}^{3}$ in April and did not exceed $1-2 \mathrm{mg} / \mathrm{m}^{3}$ during the summer and autumn periods (Fig. 9). Such values are characteristic of the non-eutrophied areas in the Baltic Sea $\left(1-5 \mathrm{mg} / \mathrm{m}^{3}\right)$.

In Haapsalu Tagalaht and Saunja Bay, on the contrary, the maximum chlorophyll $a$ concentrations $\left(10-15 \mathrm{mg} / \mathrm{m}^{3}\right)$ were measured in late summer, indicating strong eutrophication of the site. The concentrations measured in August 1989 reached even $25.7 \mathrm{mg} / \mathrm{m}^{3}$.

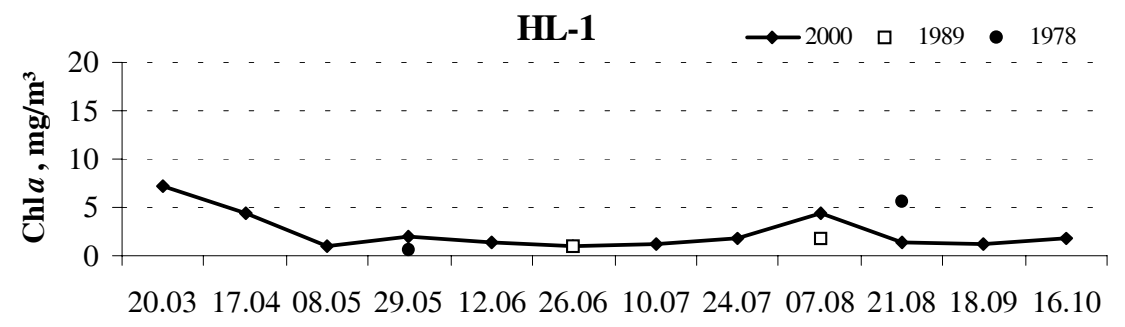

\section{HL-3}

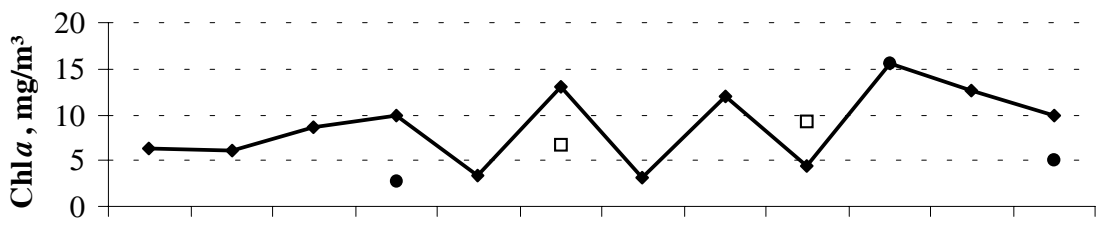

$20.03 \quad 17.0408 .0529 .0512 .0626 .06 \quad 10.0724 .0707 .0821 .08 \quad 18.0916 .10$

HL-5

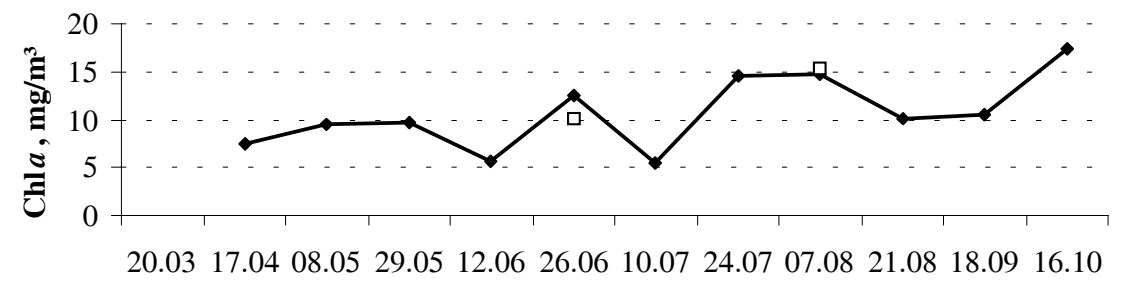

Fig. 9. Concentrations of chlorophyll $a$ in Haapsalu Eeslaht (HL-1), Tagalaht (HL-3), and Saunja Bay (HL-5). 


\section{Phytoplankton species composition and biomass}

As shown in Fig. 10, both the species composition and phytoplankton biomass differed notably between the open western and the semi-enclosed central-eastern parts of the bay. The maximum biomass values at the stations HL-3, HL-4, and

HL-1

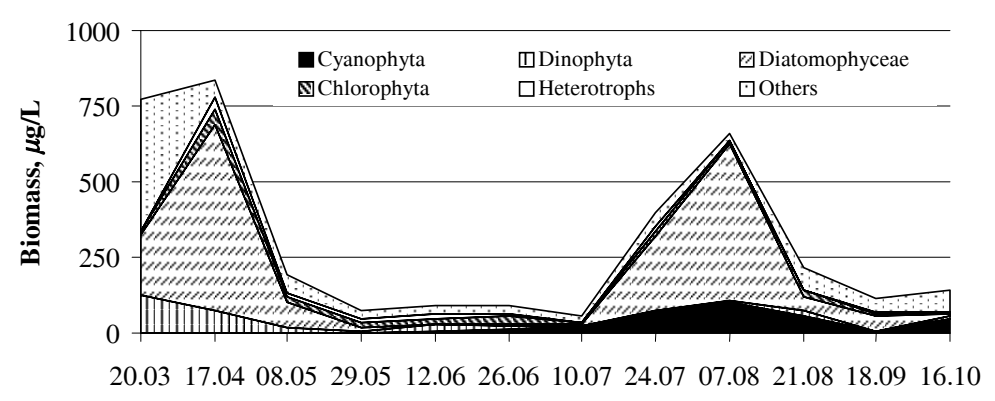

HL-3

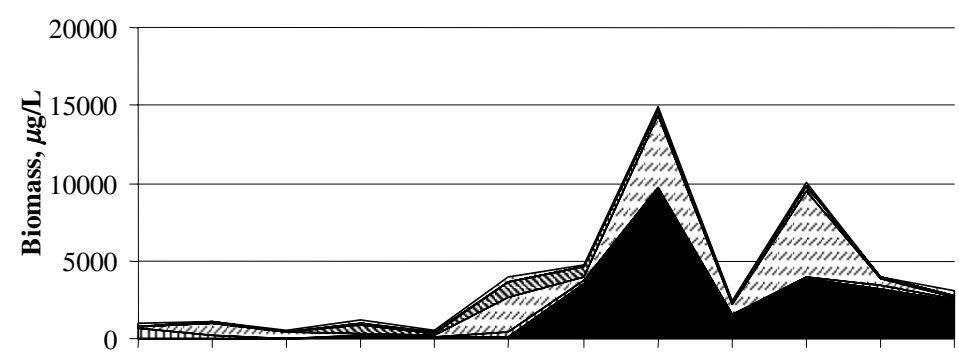

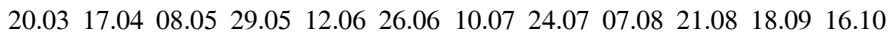

HL-5

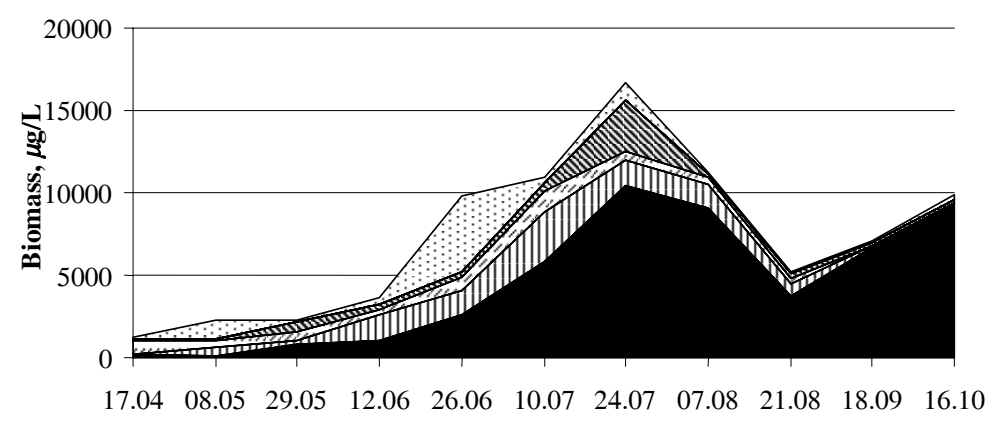

Fig. 10. Seasonal wet weight biomass dynamics of algal groups in Haapsalu Eeslaht (HL-1), Tagalaht (HL-3), and Saunja Bay (HL-5) in 2000. 
HL-5 were approximately 20 times as high as those in Haapsalu Eeslaht (stations HL-1 and HL-2). As mentioned above, the late summer annual maximum biomasses in the inner part of Haapsalu Bay refer to strong eutrophication. Typically for the non-eutrophied areas, the maximum new production period in the open western part was observed in spring.

In Haapsalu Eeslaht the dominating species during the spring maximum period was an arctic diatom, Achnanthes taeniata, and the total phytoplankton biomass did not exceed $0.8 \mathrm{mg} / \mathrm{L}$. In Haapsalu Tagalaht and Saunja Bay the diatoms Diatoma tenuis and Fragilaria spp. were responsible for the biggest biomass values in April and May. The total biomass values varied between 1.0 and $1.5 \mathrm{mg} / \mathrm{L}$.

The summer phytoplankton biomass in Haapsalu Eeslaht remained relatively low $(0.1-0.3 \mathrm{mg} / \mathrm{L})$, except during a short period at the end of July and at the beginning of August, when the diatom Cylindrotheca closterium was abundant and the total biomass values reached the spring maximum level (station HL-1). There was no clear domination of any algal group at the station HL-2 during the summer period. It was probably due to the dominance of macrophytes in that shallow area.

In Haapsalu Tagalaht and Saunja Bay the colonial blue-green algae (Merismopedia spp., Microcystis spp., Aphanocapsa planctonica, and others) prevailed from July to October. An extremely strong bloom was recorded at the station HL-5, where the total phytoplankton biomass was high until October (max $17.8 \mathrm{mg} / \mathrm{L}$ on 24 July). In Haapsalu Tagalaht the diatom $C$. closterium reached very high numbers in July and August - up to 12 million cells per litre. The species list with notes of dominance is presented in Table 1.

\section{DISCUSSION}

Despite the relatively small area of Haapsalu Bay, the differences in nutrient concentrations and phytoplankton characteristics are enormous between its open western and other parts. The main reason is that the limited water exchange between these sea areas leads to advanced eutrophication of Haapsalu Tagalaht and the eastern shallow bays. Besides, the small rivers and streams discharge nitrogen-rich fresh water and the central part of the bay receives municipal sewage waters. Although the total phosphorus load has been reduced since 1998 (Fig. 2), the nutrients accumulated in sediments still remain a source of internal loading. Moreover, the ice cover in Haapsalu Bay is a yearly phenomenon and also a very important regulating factor. As the water exchange under the ice cover is extremely low, anoxic conditions are common during late winter (Porgasaar, 1984) and the release of phosphorus from bottom sediments is possible. Additional nutrient supply in turn may lead to mass development of phytoplankton. Unfortunately, oxygen concentrations in the near bottom layer were not determined in Haapsalu Tagalaht during 2000. It is widely known that during the summer period anoxic conditions are not rare in the areas where the decomposition of organic 
Table 1. Species list of phytoplankton in Haapsalu Bay. The numbers indicate the months when the corresponding species was dominant; superscripts correspond to HL-stations

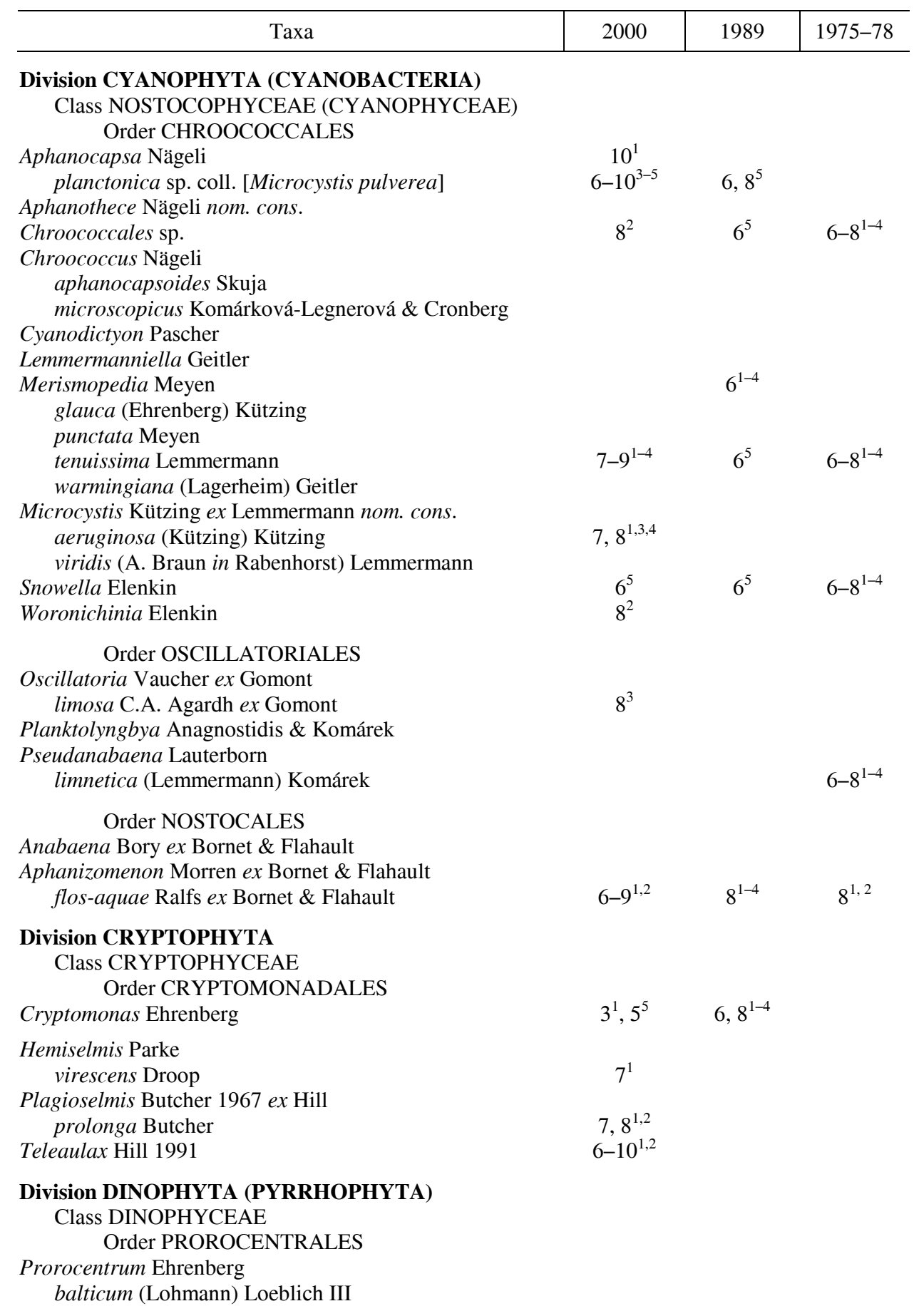


Table 1. Continued

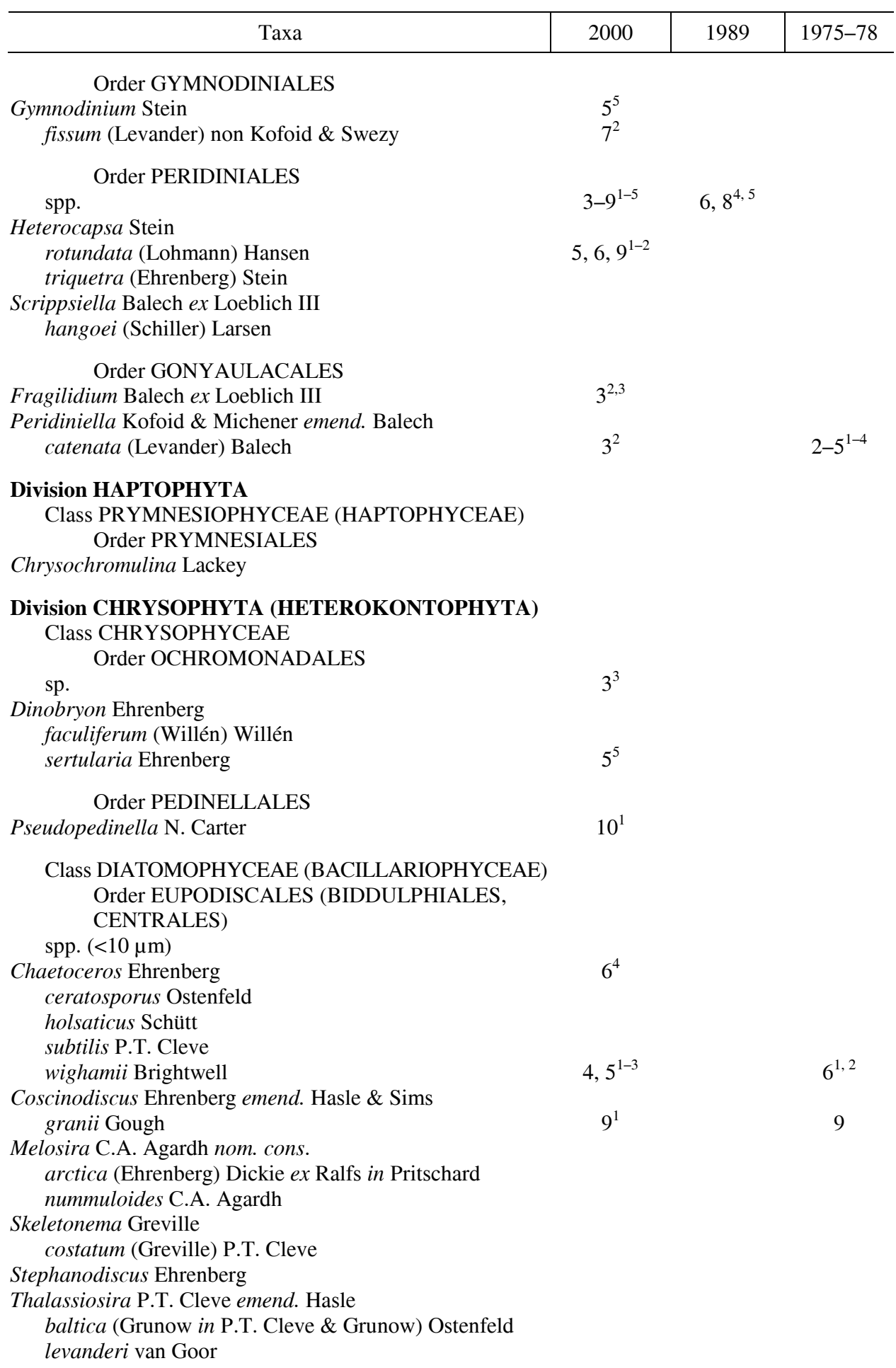


Table 1. Continued

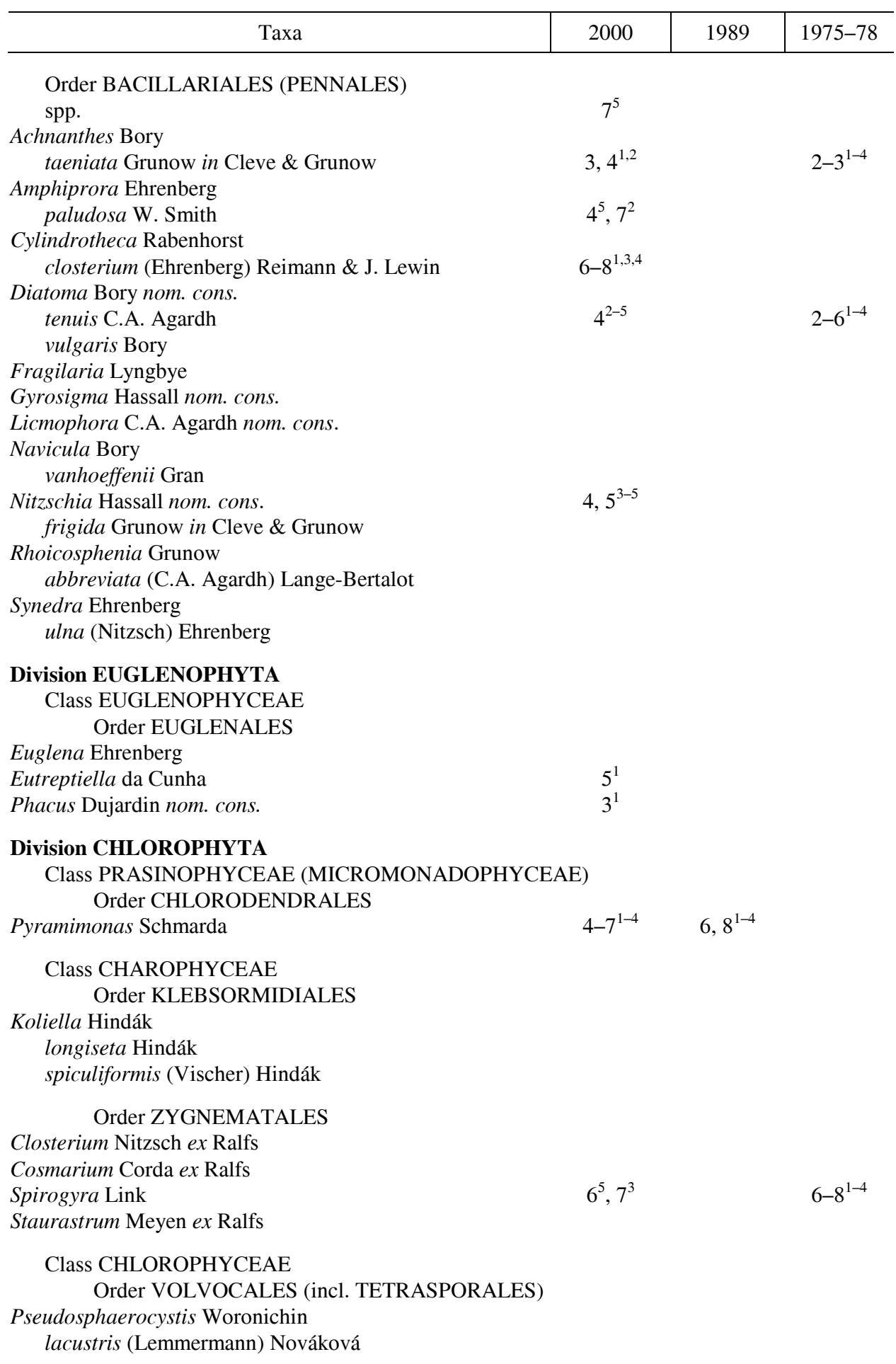


Table 1. Continued

\begin{tabular}{c|c|c|c}
\hline Taxa & 2000 & 1989 & $1975-78$ \\
\hline
\end{tabular}

Order CHLOROCOCCALES

spp.

$6^{1-5}$

Crucigeniella Lemmermann

Desmodesmus (Chodat) An, Friedl \& Hegewald

armatus (R. Chodat) Hegewald

communis (Hegewald) Hegewald

opoliensis (P. Richter) Hegewald

$6-8^{1-4}$

Dictyosphaerium Nägeli

Micractinium Fresenius

Monoraphidium Komárková-Legnerová [Ankistrodesmus]

contortum (Thuret in Brébisson) Komárková-Legnerová

$6-8^{1-4}$

Oocystis A. Braun

borgei Snow

lacustris R. Chodat

rhomboidea Fott

submarina Lagerheim

Pediastrum Meyen

boryanum (Turpin) Meneghini

Scenedesmus Meyen

acuminatus (Lagerheim) R. Chodat

arcuatus (Lemmermann) Lemmermann

ellipticus Corda

obliquus (Turpin) Kützing

Tetraëdron Kützing

caudatum (Corda) Hansgirg

minimum (A. Braun) Hansgirg

\section{Phylum CILIATA}

Mesodinium

rubrum (Lohmann) Hamburger \& Buddenbrock $\quad 5,9,10^{1-4}$

Phylum ZOOMASTIGOPHORA

Class EBRIIDEA

Order EBRIIDA [bot. EBRIALES]

Ebria Borgert

tripartita (Schumann) Lemmermann $\quad 6^{1,2}$

INCERTAE SEDIS

Katablepharis Skuja

Telonema Griessmann

subtile Griessmann

HETEROTROPHIC DINOFLAGELLATES

Amphidinium Claparède \& Lachmann

crassum Lohmann

Gymnodinium Stein

vestificii Schütt

Protoperidinium Bergh em. Balech

bipes (Paulsen) Balech

granii (Ostenfeld) Balech

$5^{2-4}$

$5^{1}$

106 
matter is intensive. In 2000 an extremely low dissolved oxygen concentration near the sea bottom was measured in Haapsalu Eeslaht $(0.8 \mathrm{mg} / \mathrm{L}$, station HL-1) at the end of July. On the other hand, dense phytoplankton communities improve oxygen conditions notably during their growing phase, particularly in eutrophied areas.

The concentrations of total phosphorus have been at their highest level under the ice cover (Porgasaar, 1982, 1984). In 2000, during the first field measurements, the ice cover was already broken in the central part of Haapsalu Bay and the concentrations of phosphorus remained relatively low. The concentrations measured during the vegetation period varied without clear pattern, but were still 2-3 times higher in the inner part of the bay than elsewhere. Porgasaar (1982) noted an increasing trend in total phosphorus concentrations in the western bay and a decrease in the inner parts in autumn. This may be associated with the influence of surface waves and turbidity during stormy weather, which can cause an about 2-3-fold increase in phosphorus concentrations (Suursaar et al., 2001). The data from 2000 do not confirm similar seasonality. As compared to other intensive coastal monitoring areas (Fig. 11), the concentrations of total phosphorus vary within wide ranges being significantly higher than in Tallinn and Narva bays. Moreover, the maximum values in Pärnu Bay (3.2 vs. $2.8 \mu \mathrm{molP} / \mathrm{L}$ in Haap-
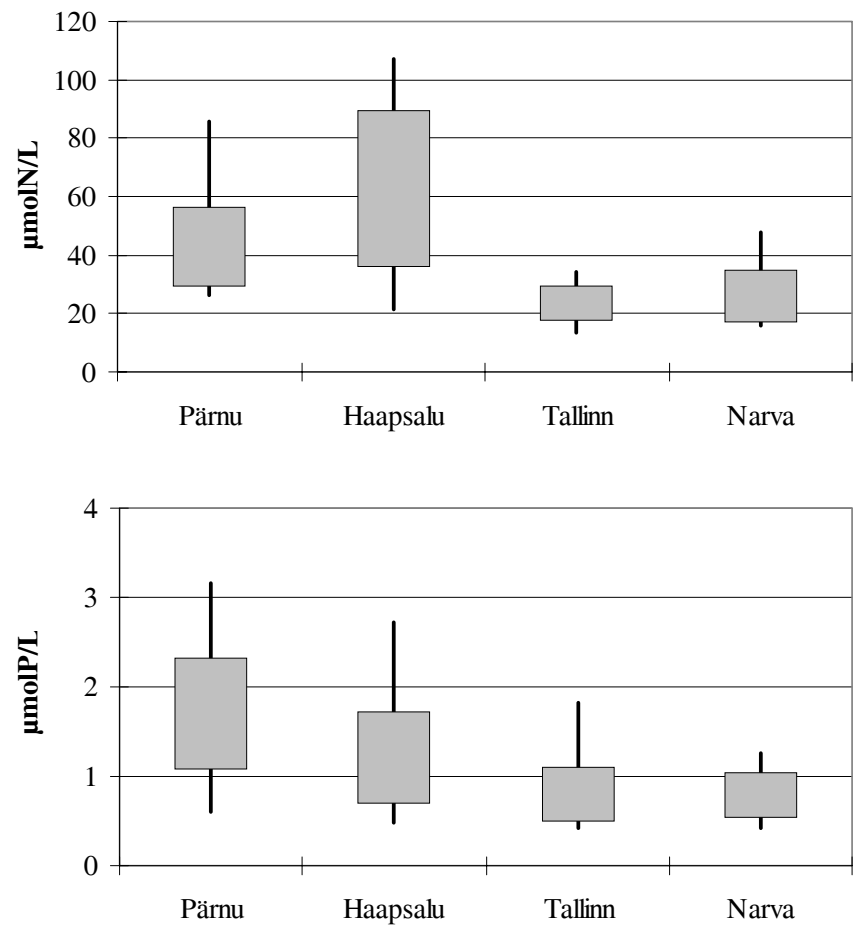

Fig. 11. The variation of total phosphorus (upper panel) and nitrogen (lower panel) concentrations in different areas of frequent monitoring in Estonian coastal waters during the vegetation period in 2000 (compiled by U. Lips). The values inside of the boxes indicate the mean \pm standard deviation. 
salu Bay) seem to be even higher. It may be concluded that Haapsalu and Pärnu bays are strongly influenced by municipal and industrial sewage waters. The corresponding maximum values for the open gulfs of Finland and Riga are 1.2-1.4 and 1-2 $\mu \mathrm{molP} / \mathrm{L}$, respectively (HELCOM, 1996).

The concentrations of total nitrogen in Haapsalu Bay are somewhat higher than in Pärnu Bay (Fig. 11). The maximum level of total nitrogen content in the open Gulf of Riga is similar to that in Pärnu Bay $(35-60 \mu \mathrm{molN} / \mathrm{L})$ but considerably higher than in the Gulf of Finland. It has to be mentioned that the variability of this parameter was noteworthy during the observation period in Haapsalu Bay. On the ground of measurements performed in the 1980s, Porgasaar (1993) noticed a decreasing trend of total nitrogen towards the western part and the maximum values were obtained in the easternmost part of the bay. In 2000 total nitrogen concentrations followed a similar pattern at all stations with the exception of the station HL-5, where the level of nitrogen was evenly high during the late summer and autumn.

The content of dissolved inorganic phosphorus (DIP) showed rather irregular seasonal dynamics in Haapsalu Bay. Only at the station HL-4, close to the sewage outlet, the concentrations of phosphates were more fluctuating with a notable peak $(0.9 \mu \mathrm{molP} / \mathrm{L})$ on $10 \mathrm{July}$. In 1979 some high concentrations were obtained in the central and eastern parts of the bay $(2.2-2.3 \mu \mathrm{moP} / \mathrm{L}$; Porgasaar, 1984, 1993), but in general the level of DIP remained reasonably low in the whole bay during all observations. Occasionally high concentrations may be related to the inflow of sewage from the town. As a rule, the content of DIP is higher during the winter and decreases during the intensive vegetation of phytoplankton. Therefore, only winter concentrations of inorganic nutrients can be used for the estimation of the trophic status.

A controversial precept of aquatic ecology asserts that low ratios of nitrogen to phosphorus $(\mathrm{N}: \mathrm{P})$ lead to noxious and sometimes toxic blooms of blue-green algae (cyanobacteria). Some recent investigations show that the risk of water quality degradation by blue-green algal blooms is more strongly correlated with variation in total $\mathrm{P}$, total $\mathrm{N}$, or standing algae biomass than the ratio of $\mathrm{N}: \mathrm{P}$ (Downing et al., 2001). Thus, a simple increase in nutrient concentrations and algal biomass is more associated with risks of cyanobacteria than low N:P ratios. Guildford \& Hecky (2000) affirm that phytoplankton biomass, as indicated by chlorophyll $a$, shows a positive relationship with total $\mathrm{P}$ both in the freshwater and ocean environment. Thus, P-deficient phytoplankton growth was inferred when total $\mathrm{P}$ was $<0.5 \mu \mathrm{mol} / \mathrm{L}$ and $\mathrm{N}$-deficient growth was apparent at $\mathrm{TN}: \mathrm{TP}<20$ (molar). Calculations made for the total phosphorus vs. chlorophyll $a$ concentrations in Haapsalu Bay in 2000 indicated a moderate positive correlation $\left(r^{2}=0.36 ; n=57\right)$, whereas the relationships between total nitrogen and chlorophyll $a$ were weak $\left(r^{2}=0.05 ; n=57\right)$. A strong correlation between total phosphorus and phytoplankton biomass in Estonian coastal waters was also found by Piirsoo (1996). It may be concluded that phosphorus has a stronger effect on phytoplankton biomass growth in eutrophied coastal areas than nitrogen and that the influence of nitrogen removal cannot be very efficient from this aspect. 
Chlorophyll $a$ concentrations and phytoplankton biomass followed similar seasonal patterns in 2000 and during the earlier observations. No significant changes in chlorophyll $a$ concentrations were detected in 2000 as compared with 1976-79 and 1989. The highest instability was recorded at the station HL-4, which may be related to an increased nutrient (especially phosphorus) supply due to sewage outflow or vertical mixing of water masses. The highest concentration of chlorophyll $a-65.7 \mathrm{mg} / \mathrm{m}^{3}$ - for the whole bay was measured in the vicinity of the sewage outlet in August 1989. In the late 1970s and in 2000 the concentrations in the inner part of Haapsalu Bay did not exceed $15 \mathrm{mg} / \mathrm{m}^{3}$ during the summer period. In October 2000, the maximum values were recorded at the stations HL-4 and HL-5 $\left(16.9-17.4 \mathrm{mg} / \mathrm{m}^{3}\right)$. An intensive development of phytoplankton in the autumn period was observed also in the 1970s (Porgasaar, 1982).

Comparison of the dominant species of phytoplankton and biomass calculations are problematic in some cases. Methods of sampling and analysis are under continual development and also numerous taxonomic changes have occurred during the last decades. Despite that we can say that the general succession of phytoplankton communities in Haapsalu Bay has not altered and the biomass values obtained in 2000 are similar to those calculated from the earlier samples.

The highest biomasses in Saunja Bay in late summer 2000 (up to $8.6 \mathrm{mg} / \mathrm{L}$ ) were formed by the colonial blue-green alga identified as Aphanocapsa planctonica. In the report from 1989, the dominant species in the same bay was called Microcystis pulverea (see Table 1). As the species is probably incorrectly identified in both cases, it would be right to make comparisons on order level (Chroococcales). The flagellates, identified earlier as Cryptomonas spp., are now split into different genera (Hemiselmis, Plagioselmis, Teleaulax). In general, the dominant species are overlapping, and in some cases they are identified only to genus or order level.

Unlike in 2000, in 1989 the maximum total biomass of phytoplankton in Saunja Bay was recorded in June $(33.2 \mathrm{mg} / \mathrm{L})$. In 2000 both in the central (stations HL-3 and HL-4) and eastern (station HL-5) parts of the bay the annual maximum was observed in August. The biomass varied in the eastern part of Haapsalu Bay in August 1985, 1989, and 2000 in the range 0.8-8.2, 1.8-12.9, and $5.2-13.3 \mathrm{mg} / \mathrm{L}$, respectively. In a report from 1989, A. Randveer noted an about 3-fold increase in the share of blue-green algae in total phytoplankton in the eastern bay compared to August 1985. In 2000 the relative biomass of blue-green algae increased rapidly from July ascending continuously until October to reach up to $93-94 \%$ of total. A high percentage of blue-green algae in July-October was also observed in the central part of the bay (39-88\%), while in the open western part it varied between 4 and $43 \%$ at the very low total biomass values.

Like in the case of chlorophyll $a$, the proliferation of phytoplankton in September and October was common in Haapsalu Bay also in the 1970s (Piirsoo, 1984). However, the maximum biomass values obtained in the late 1970s do not exceed $3.0-3.5 \mathrm{mg} / \mathrm{L}$ (near the station HL-4) and in most cases remain even below $1 \mathrm{mg} / \mathrm{L}$ during the summer period. The corresponding average biomass values in August 1976-85, 1989, and 2000 were $0.1-1.8,3.3$, and $7.2 \mathrm{mg} / \mathrm{L}$. The phytoplankton biomass in the open western part was relatively low $(<1 \mathrm{mg} / \mathrm{L})$ during all observations. 


\section{CONCLUSIONS}

The ecosystem of Haapsalu Bay is characterized by very high biological variability. The concentration of chlorophyll $a$ and total phytoplankton biomass may differ 15-20 times between the western open and eastern shallow parts of the bay. Typically for the eutrophied sea areas, the most intensive development of phytoplankton is shifted to the late summer period in the central and eastern parts of the bay (Haapsalu Tagalaht and Saunja Bay), while the succession in the western part (Haapsalu Eeslaht) is similar to that in non-eutrophied coastal waters.

The concentration of total phosphorus plays a decisive role in the functioning of the Haapsalu Bay ecosystem. Moderate or strong positive correlation was found between this parameter and the phytoplankton biomass development during different observation periods. Despite the reduction of the pollution load after the reconstruction of the municipal wastewater treatment plant and technological developments, a large amount of phosphorus has accumulated in the sediments, functioning as an additional nutrient supply for phytoplankton in the case of favourable environmental conditions - vertical mixing of water masses and also by oxygen deficiency. The effect of nitrogen load on the biological productivity is probably less important.

\section{ACKNOWLEDGEMENTS}

I am grateful to Arno Põllumäe, Inga Lips, Urmas Lips, Laur Mägi, and the staff of the Läänemaa County Environmental Department for assistance in field observations. This project was financed by the Estonian Ministry of the Environment.

\section{REFERENCES}

Downing, J. A., Watson, S. B. \& McCauley, E. 2001. Predicting cyanobacteria dominance in lakes. Can. J. Fish. Aquat. Sci., 58, 1905-1908.

Guildford, S. J. \& Hecky, R. E. 2000. Total nitrogen, total phosphorus, and nutrient limitation in lakes and oceans: is there a common relationship? Limnol. Oceanogr., 45, 1213-1223.

HELCOM, 1988. Guidelines for the Baltic monitoring programme for the third stage. Baltic Sea Environ. Proc., 27D.

HELCOM, 1996. Third periodic assessment of the state of the marine environment of the Baltic Sea, 1989-1993; Background document. Baltic Sea Environ. Proc., 64B.

HELCOM, 2001a. Environment of the Baltic Sea area 1994-98. Baltic Sea Environ. Proc., 82A.

HELCOM, 2001b. Thematic reports on HELCOM PITF regional workshops held in the Baltic republics. Baltic Sea Environ. Proc., 83, 87-91.

Hillebrand, H., Dürselen, C.-D., Kirschtel, D., Pollingher, U. \& Zohary, T. 1999. Biovolume calculation for pelagic and benthic microalgae. J. Phycol., 35, 403-424.

Jeffrey, S. W. \& Humphrey, G. F. 1975. New spectrophotometric equations for determining chlorophylls $a, b, c_{1}$ and $c_{2}$ in higher plants, algae and natural plankton. Biochem. Physiol. Pflanzen, 167, 191-194. 
Mardiste, H. 1974. Physico-geographical and hydrological peculiarities of the straits Muhu (Moonsund area). Abstract of Cand. Sci. (PhD) thesis. Tartu (in Russian).

Piirsoo, K. 1984. The phytoplankton of Haapsalu Bay and its seasonal dynamics. In Hydrobiological Regime of the Baltic Sea. Hydrobiological Researches, Vol. XIII (Järvekülg, A., ed.), pp. 24-33. Acad. Sci. Estonian SSR, Tallinn (in Russian).

Piirsoo, K. 1996. Environmental factors regulating the phytoplankton biomass in Estonian coastal waters. In Proceedings of the 13th Symposium of the Baltic Marine Biologists, pp. 73-77. Zinatne, Riga.

Porgasaar, V. 1982. Hapniku-, fosfori- ja klorofüllisisaldus Eesti NSV rannikumere eutrofeerunud piirkondades. In Eesti NSV rannikumere kaitse (Järvekülg, A., ed.), pp. 40-48. Valgus, Tallinn.

Porgasaar, V. 1984. Chlorophyll a content and hydrochemical conditions in Haapsalu Bay in 19761979. In Hydrobiological Regime of the Baltic Sea. Hydrobiological Researches, Vol. XIII (Järvekülg, A., ed.), pp. 9-23. Acad. Sci. Estonian SSR, Tallinn (in Russian).

Porgasaar, V. 1993. Content and distribution of phosphorus and nitrogen in the coastal waters of West Estonia. Proc. Estonian Acad. Sci. Ecol., 3, 166-180.

Suursaar, Ü., Kullas, T. \& Otsmann, M. 2001. The influence of currents and waves on ecological conditions of the Väinameri. Proc. Estonian Acad. Sci. Biol. Ecol., 50, 231-247.

\section{Haapsalu lahe veekeskkond aastail 1975-2000}

\section{Andres Jaanus}

Kitsas $(2-4 \mathrm{~km})$ ja madalaveeline $(<5 \mathrm{~m})$ Haapsalu laht jaguneb aktiivse veevahetusega lääneosaks (Eeslaht) ning munitsipaal- ja tööstusheitvete mõju all olevaks kesk- ja idaosaks (Tagalaht ja Saunja laht). Aastal 2000 koguti 12 kompleksse välimõõtmiste seeriaga märtsist oktoobrini materjali veekeskkonna füüsikaliste, keemiliste ja bioloogiliste parameetrite kohta (temperatuur, soolsus, hapnikusisaldus, läbipaistvus, biogeenide sisaldus, klorofüll $a$ sisaldus, fütoplanktoni liigiline koosseis ja biomass). Saadud tulemusi on võrreldud varasemate uuringute andmetega aastatest 1975-1990.

Üldfosfori- ja klorofüll $a$ sisalduse vahel leiti mõõdukas positiivne korrelatsioon $\left(r^{2}=0,36 ; n=57\right)$, samas oli seos üldlämmastiku- ja klorofüllisisalduse vahel nõrk $\left(r^{2}=0,05 ; n=57\right)$. Saunja lahes täheldati sinivetikate suhtelise biomassi kasvu kuni oktoobrini (maksimum 93-94\% kogubiomassist). Haapsalu Tagalahes varieerus sinivetikate osakaal kasvuperioodil 39-88\% ning Eeslahes 4-43\%. Fütoplanktoni külluslik produktsioon lahe idaosas oli iseloomulik juba 1970. aastatel. Kui aastatel 1976-1985, 1989 ja 2000 saadi kogu fütoplanktoni keskmiseks biomassiks vastavalt $0,1-1,8 ; 3,3$ ja 7,2 mg/l, siis lahe idaosas oli sama näitaja vahemikus $0,8-8,2 ; 1,8-12,9$ ja $5,2-13,3 \mathrm{mg} / \mathrm{l}$. Kuigi fütoplanktoni koosluste üldine suktsessioon Haapsalu lahes pole viimastel aastakümnetel muutunud, põhjustab toitainesisalduse kasv sinivetikate osakaalu suurenemist koos sellest tuleneva keskkonnariskiga. 